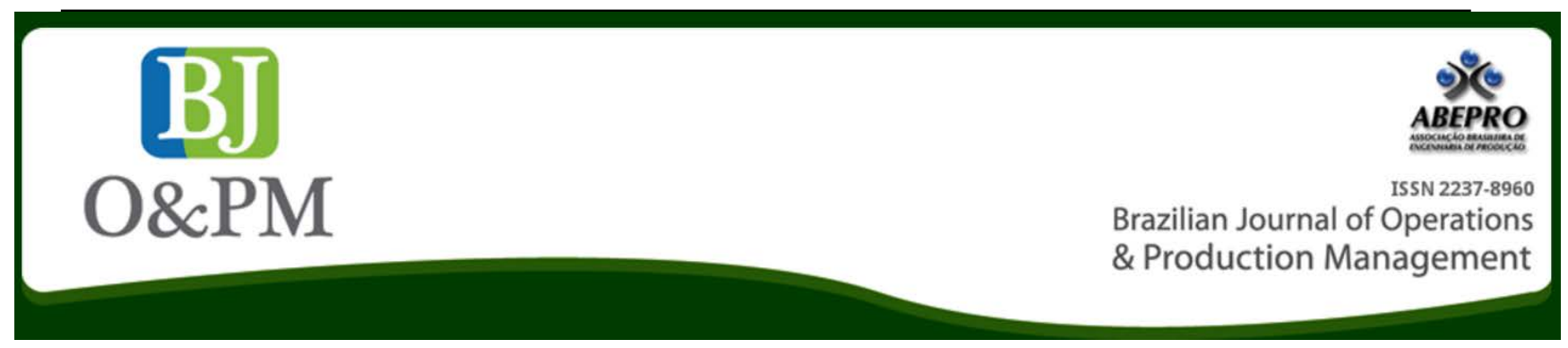

\title{
SUSTAINABLE WASTE MANAGEMENT: A CASE FROM INDIAN CEMENT INDUSTRY
}

\author{
Priyanka Pathak ; Sumit Gupta ${ }^{a}$; Govind Sharan Dangayach ${ }^{a}$ \\ ${ }^{\text {a }}$ Malaviya National Institute of Technology Jaipur
}

\section{Resumo}

Sustainability means meeting the needs of the present without compromising the ability of future generations to meet their own needs, and Sustainable Waste Management is using waste produced efficiently so that use of amount of material resources get reduced. India, is the second amongst cement producers in the world with a total capacity of 245.40 Million Tonnes (MT), has a huge cement industry and produces about $7 \%$ of world's total production. The Indian cement industry has on one hand, enormous pressure to increase profit and margins, while on other; there is considerable public interest on a sustainable and environment friendly usage of natural resources. The objective of this paper is to pursue sustainable waste management for a cement industry through replacement of coal with some alternative fuel (Tyre Derived Fuel), which actually belongs to the group of hazardous wastes and which could benefit the plant economically and environmentally, and improve sustainability of plant. For the study co-processing of waste is adopted as method for replacement of fuel.The use of alternative fuels will help in reducing energy costs and providing a competitive edge for a cement plant. Furthermore, this will reduce the burden of waste disposal considerably. So, it also supports to fulfilling Sustainable Waste Management issues.

Palavras-chave: Sustainability; Sustainable Waste management; Hazardous Waste; Alternative Fuels.

\section{INTRODUCTION}

In 1987 the World Commission on Environment and Development sought to address the problem of conflicts between environment and development goals by formulating a definition of sustainable development [1] "Sustainable development is development which meets the needs of the present without compromising the ability of future generations to meet their own needs." (World Commission on Environment and Development, 1987). There has been a growing recognition of three essential aspects of sustainable development, which are Economic, Environmental and Social aspects.

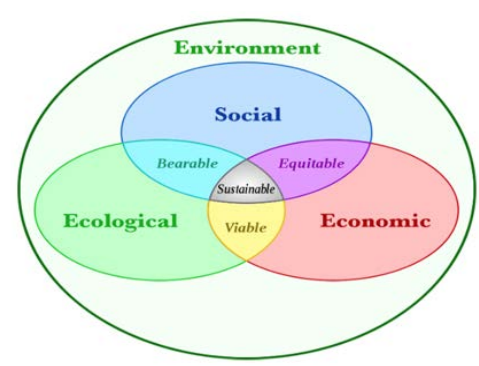

Fig 1.1: The "three pillars" of sustainability bounded by the environment

Sustainable waste management: Using material resources efficiently to cut down on the amount of waste reduced. And, where waste is generated, dealing with it in a way that actively contributes to the economic, social and environmental goals of sustainable development [2]. The different waste management options can be organized in an order known as the waste management hierarchy that reflects the relative sustainability of each. 

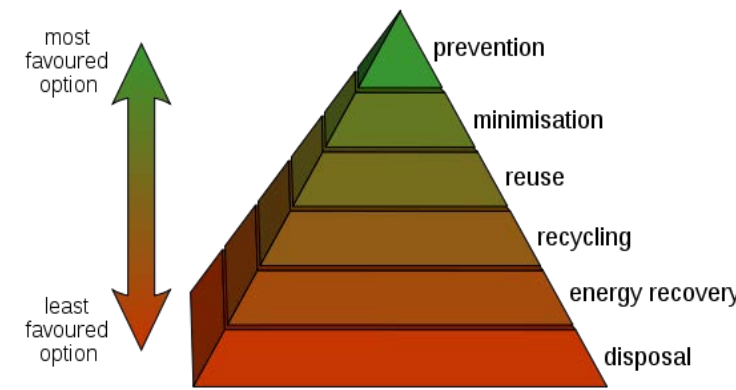

Fig 1.2: Waste Management Hierarchy [3].

India, is the second amongst cement producers in the world with a total capacity of 245.40 Million Tonnes (MT) as on 31st March 2011, has a huge cement industry and produces about $7 \%$ of world's total production. Cement plants are an essential part of India's industrial landscape and are increasingly important partners in innovative waste management solutions, called co-processing. Co-processing waste in this way consists of using both the calorific potential to heat the kiln and the material component from the fuel ash as a raw material, it also has a direct impact on lowering $\mathrm{CO} 2$ emissions, since it reduces the quantity of natural raw materials needed for clinker production.

Several cleaner production programs were implemented by the government, to build the capacity of industries in meeting new environmental policies. Some of the cement plants in the country had been authorized by CPCB for using biomass, waste oils, and rubber wastes (tires land mouldings) for use as alternative fuel (AF) for coal after successful trial runs [3]. A cement plant consumes 3,000 to $6,500 \mathrm{MJ}$ of fuel per tonne of clinker produced, depending on the raw materials and the process used. Most cement kilns today use coal and petroleum coke as primary fuels, and to a lesser extent natural gas and fuel oil. As well as providing energy, some of these fuels burn to leave fuel ash containing silica and alumina compounds (and other trace elements). These combine with the raw materials in the kiln contributing to the structure of the clinker and form part of the final product. It has been reported that the costs associated with fuels in a cement plant can be as high as 30 to 40 percent of the total production costs. Recently, Central Pollution Control Board has come up with guidelines on use of Alternative fuel for Cement Industry. It will not only solve the problem of waste management to significant level but also reduce use of fossil fuel. In addition to energy recovery, there is also a corresponding saving relevant to $\mathrm{CO} 2$ emissions released into the atmosphere, since waste replaces other fossil fuels producing greater $\mathrm{CO} 2$ levels.

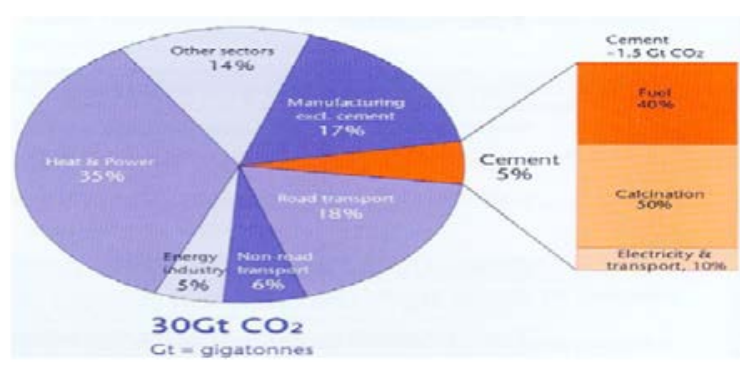

Fig 1.3: Cement Industry Share in $\mathrm{CO} 2$ Emissions [4].

Co-Combustion or Co-processing of alternative fuels and raw materials (AFRs) and hazardous wastes in cement kilns will usually constitute one tool in a complete toolbox, complementary with other treatment options. The coprocessing of waste has been recognized as a recovery operation under EU legislation. Co-processing is a sustainable development concept based on the principles of industrial ecology.

\subsection{Alternative Fuels}

Any materials or substances that can be used as fuels, other than conventional fuels, known as Alternative fuels, Conventional fuels include: fossil fuels (petroleum (oil), coal, and natural gas). Alternative fuels can also be the waste \& by-products of other industries [5].

\subsubsection{Classification of Alternative Fuels}

Alternative fuels used in the cement industry instead of coal, are usually classified according to the concentration criterion into :

1. Gaseous (examples: landfill gas, pyrolysis gas),

2. Liquid (examples: solvents, waste oils, greases),

3. Solid (examples: animal powder, bark, paper, tyres, rubber wastes, plastics, fluff).

\subsubsection{Adaptability of Alternative Fuels}

The burning of various types of wastes requires the detailed control and adaptation of technological processes to each type of waste. For this reason, alternative fuels are derived from wastes having similar composition and properties [6]. As a mixture of various wastes, alternative fuels must be produced in conformity with certain rules:

- The chemical quality of the fuel must meet regulatory standards assuring environmental protection, 
- The calorific value must be stable enough to allow the control of the energy supply to the kiln; the objective being to arrive at a fairly homogeneous composition, and

- The physical form must allow easy handling of the material for transportation and a stable, adjustable flow of material in the cement plant.

\subsection{The Effects of Hazardous Waste on Cement}

The engineering performance of Portland cement is largely unaffected by small additional quantities of heavy metal or certain non metallics, e.g., phosphorous. There is an upper limit (in the $1 \%$ by weight of clinker range $10,000 \mathrm{ppm}$ ) above which these compounds start to affect the setting and hardening properties of cement [7]. This particularly applies to lead, zinc, chromium and phosphorous compounds. Rather large quantities of the refractory metals $(\mathrm{Ba}, \mathrm{Cr}, \mathrm{Ni}, \mathrm{V})$, perhaps exceeding $1 \%$ can be accommodated in the clinker minerals without deleterious effect. However, these metals $(\mathrm{Cd}, \mathrm{Pb}, \mathrm{Hg})$ can be stabilized as complex minerals in various aluminium silicate materials similar to some clays. Arsenic, being close in proximity to silicon (in the Periodic Table), is believed to replace silicon in the crystal lattices of cement minerals. Quite small amounts of lead and zinc may retard the setting and especially the hardening of cement if they are added in the mixing. The presence of oxides of lead, zinc and boron disturb the phenomenon of setting the cement. Also wastes can cause problem of cement solidification with the set, cure, and permanence of the cement, unless the wastes are pre-treated. The hazardous waste burning cement industry needs to stop accepting the hypothesis that significant levels of heavy metals from waste burning do not cause problems with the clinker since these metals must incorporate in the mineral structure of the clinker.

\section{LITERATURE REVIEW}

The cement manufacturing process involves three key steps, including preparing and grinding the raw materials, heating the newly formed clinker in a kiln, and final production of cement through grinding. Figure below lists the overall production and GHG emissions flow for cement production. For the first step, through the use of drilling, blasting, and crushing machine $\mathrm{s}$, mined limestone and other materials are converted to small pieces with an average size of 0.39 inch (about $1 \mathrm{~cm}$ ) in diameter. These materials are grounded to very fine powders and blended with the correct proportions. The use of purchased electricity is the main source of GHG emissions during this step (embodies emissions). The second step (calcining process) takes place in a rotary kiln that is fired by fossil fuels at a very high temperature (usually about 1400 degree C -500 degree C) so that the raw meal can be converted into dried material after the grinding process. The material formed in the kiln is named as "clinker" and is typically composed of rounded nodules between $1 \mathrm{~mm}$ and $25 \mathrm{~mm}$. In this process calcium carbonate breakdown releases $\mathrm{CO}_{2}$ and at the same time a large amount of fossil fuels and electricity are consumed, generating GHG emissions. For the third step, the cooled clinker is grounded again in a rotating finishing mill. A combination of gypsum and clinker substitution is added to the heated cement during this step. The final products are packed and distributed to final consumers. GHG emissions during this step come from purchased electricity consumed by grinding machines and packaging machines, as well as the fuel emissions for final delivery.

Due to complex material and energy flows for cement production, the investigation of GHG emissions inventory for cement industry is also complicated. Research efforts have been made on establishing guidelines for GHG accounting of cement industry during the last two decades. For instance, IPCC developed $\mathrm{CO}_{2}$ accounting methods for cement production process in IPCC national GHG guidelines (IPCC, 2006). The Cement Sustainability Initiative (CSI) of the World Business Council for Sustainable Development(WBCSD) released "The Cement $\mathrm{CO}_{2}$ and Energy Protocol" (version 3) in 2011 (CSI, 2011), providing a detailed accounting method on GHG emissions for cement production.

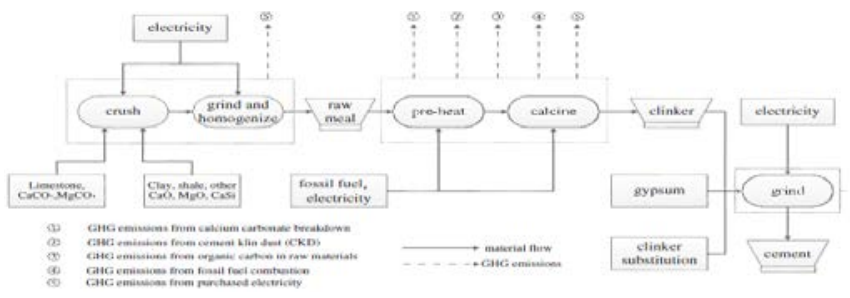

Fig 2.1: The Overall Flowchart for Cement Production and Related GHG Emissions.

Ever since the first energy crises of 1974, World attention was drawn towards harnessing non-conventional energy sources to substitute costly and depleting fossil fuel. Since then mention of energy from the waste do find a place in all articles which try to present possible sources of cheap and renewable energy.

The growth of chemical industries in developed and developing countries resulted in the release of huge quantities of hazardous waste into the environment in the form of solid, liquid and gas. Such type of wastes posed substantial hazard when improperly disposed $[7,8]$. In India, detoxification, destruction and solidification of hazardous waste for safe and secured disposal is non-existent in most of the industrial units. Most of the highly hazardous industrial sectors dispose their waste in low-lying area because of the fact that economical aspects outweigh the environmental aspects. 
The control mechanisms for the treatment and safe disposal of hazardous wastes were through the regulations by the ministry. The Hazardous Waste (Management and Handling) Rules, 2008 comprise of the guidelines for guiding the local authorities in the management of Hazardous Waste. The guidelines are meant for guiding the local authorities in the management of hazardous wastes. The guidelines also provide necessary details for the occupier, generator, transporter and operator of the disposal facility Out of many methods of disposal of hazardous waste, the disposal by incineration is one of the environmentally sound methods as compared to other methods of disposal practised in India [9]. The main problem associated with the incineration of hazardous waste was generation of air pollution reported by many workers.

In hazardous wastes disposal cement kilns can play an integral role in hazardous waste management together with other disposal technologies. Using cement kiln technology has economic and environmental benefits reported by many researchers.

It has been found that many countries like USA, UK, France, Australia, Norway, Italy, Sweden, Canada, and Singapore are using hazardous waste as fuel in cement kiln for cement manufacture. It has been found that 3 cement plants of Onoda Cement Co. Japan are using 26 types of industrial wastes delivered from 252 industries with annual consumption of 131000 tonnes of waste as fuel. As a result, $1,10,000$ tonnes of coal was saved per year and accordingly the fuel cost was reduced by $6.9 \%$ [10]. The investment in the equipment is about 73.6 million US dollars and the interest and depreciation expenses account for $130 \%$ of the reduced cost assuming that the invested money will be recovered in 10 years.

\subsection{Objectives of Study}

The key objectives of study are given below.

- To understand the utility of hazardous waste as alternative fuel in cement manufacturing.

- With the help of cost, availability and accessibility factors analyzing the sustainable waste.

- Finding Benefits of using alternative fuels for a cement plant.

\subsection{Kiln Suitability For Destruction Of Wastes}

The process of clinker burning in a rotary kiln creates favourable conditions for the use of waste materials as alternative fuels. These include:

- High temperature,
- Alkaline environment,

- Oxidizing atmosphere,

- The lack of incineration wastes as all metallic and non-metallic incineration products undergo a complete absorption,

- Large heat-exchange surface,

- Good mixture of gases and products, and

- Sufficient time (over $2 \mathrm{~s}$ ) for the disposal of hazardous wastes.

\subsection{Waste Classification}

- Waste can be classified as:

- Hazardous waste

- Non-Hazardous waste

\subsubsection{Non-Hazardous Waste}

Some of the cement plants in the country had been testing fuels made from municipal waste, few industrial wastes, or their mixtures for use as alternative fuel (AF) for coal [11]. Non-hazardous waste majorly contributes as alternative raw material, since calorific value of such waste is low.

\subsubsection{Hazardous Wastes}

As the alternative Fossil Fuels (Lignite and Pet coke) has limited availability, Hazardous Combustible Wastes can be looked as an option to co-process along with the primary fuel. The hazardous incinerable waste has vast potential to be used as a supplementary resource or for energy gradient recovery on Co-combustion. Their higher calorific value / constituents, which are ingredients of cement evolve scope of its utilization as a supplementary resource material in the cement industry.

USEPA defined the hazardous waste as "Wastes or combination of Wastes that pose a substantial presence or potential hazard to human health or living organism [12] ."

\section{Classification of Hazardous Waste}

The classification is given below:

1) Solid hazardous wastes:

a) Paint residue

b) Spent carbon residue

c) Distillation residue

d) Phosphorus residue etc. 
2) Semi-solid hazardous waste:

a) Tank bottom sludge

b) Oily sludge

c) Liquid slurry

d) Tarry waste

e) Filter aid sludge etc

3) Liquid hazardous wastes:

a) Cleaning agents like mineral turpentine

b) Waste oil

c) Tarry waste

d) Amines waste etc.

\subsection{Hazardous Waste Situation in India}

The category-wise classification of this quantity is as follows [13].

- Land Fillable HW - 27,28,326 MTA (Metric Tonnes/ Annum)

- Incinerable HW - 4,15,794 MTA

- Recyclable HW - 30,88,387 MTA

It is obvious that the recyclable portion of HW is in the range of $49.55 \%$ and is more than other two categories. The land disposable portion and incinerable portion are in the tune of $43.78 \%$ and $6.67 \%$ respectively.

\section{RESEARCH METHODOLOGY}

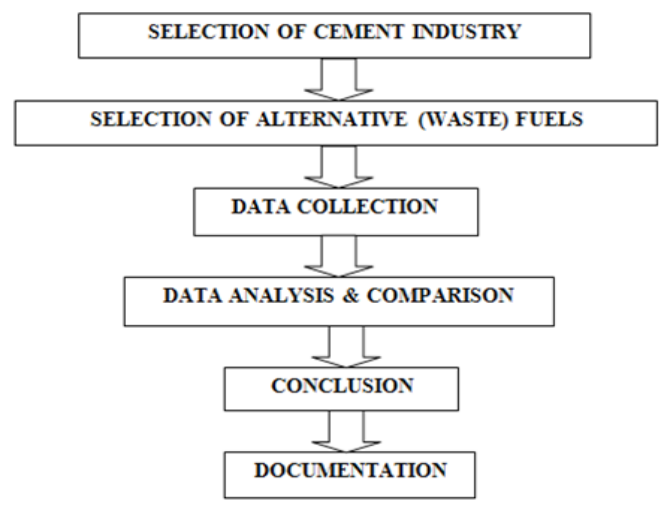

Fig 3.1: Flow Chart for Research Methodology [13].

After selecting a cement industry, TYRE DERIVED FUEL is selected as a waste to be used as alternative fuel in kiln then following data is collected for it:
INDIVIDUAL DATA

- Proximate Analysis Data

- Ultimate Analysis Data

- Data for Heavy Metal Analysis of Fuel

- Data for Emissions by fuel

COMBINATION DATA

- Fuel mix Data for Coal \& TYRE DERIVED FUEL

After the data collected in the tabular form for 'fuel mix' elemental analysis and emissions were compared with the standard tables provided for primary fuel COAL.

After making the comparison, final conclusions were taken, as which percentage of fuel mix is better to be used there so that coal consumption and related cost can be reduced, also with the lesser GHG emissions, as sustainability is our prime consideration. And it is also kept in mind that the selected fuel mix are really available at a lesser price with easy accessibility.

In the research methodology our main emphasis is on co-processing of Hazardous waste and the process used in cement industry for the same. The hazardous wastes for co-processing need to be handled in an environmentally safe manner avoiding the possibilities of contaminating the nearby environment and eliminate the chances of accidents leading to environmental catastrophe. So, we are interested in finding following information:

- Requirements For Co-Processing Of Waste

- Feeding Of Materials For Co-Processing

- Suitability Of Substances For Co-Processing

- Operating Conditions

- Air Pollution Control Requirements

- Emission Standards

- Monitoring Requirements

\section{Basic Process Adopted}

Limestone is extracted from the quarry and is transported to the crusher by dumpers. Limestone is crushed to the desired size and is blended in large stockpiles. If required, corrective materials are added to achieve the desired raw mix. Raw materials are converted to fine powder in the raw mill and stored in large blending silos.

Coal is brought from outside, crushed at the coal crusher and ground to fine powder in the coal mill, to be used as fuel along with other waste fuels for firing in the pre-heater and kiln system. The raw meal stored in the silos goes through 
the pre-calciner and is pre-heated before going into the kiln.

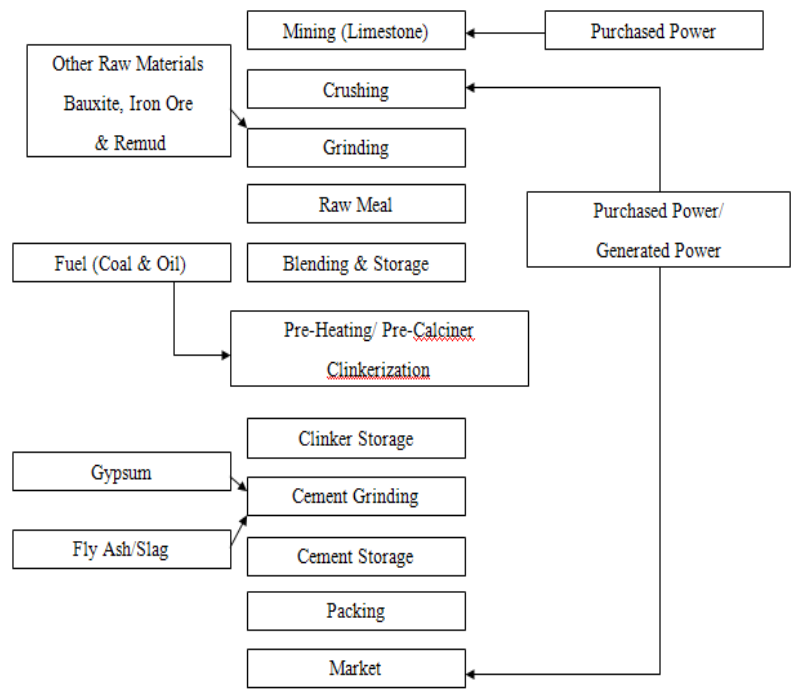

Fig 3.2: Cement Manufacturing Process.

Pre-calcined raw meal is burnt inside the kiln at a high temperature to produce clinker. Hot clinker is then cooled and stored in stockpiles or silos. At the Cement Mill, clinker, gypsum, other additives and cementitious materials are added to make cement. The cement is then stored in blending silos and is packed and distributed to different places in bags or bulk containers from the packing plant [14].

\subsection{Operating Conditions for Using Waste In Kiln}

a) Co-processing plants shall be designed, equipped, built and operated in such a way that the gas resulting from the co-processing is raised in a controlled and homogeneous fashion and even under the most unfavourable conditions, to a temperature of $950^{\circ} \mathrm{C}$ for two seconds. For hazardous wastes with a content of more than $1 \%$ halogenated organic substances (expressed as chlorine), the temperature has to be raised to $1100^{\circ} \mathrm{C}$.

b) Co-processing plants shall have and operate an automatic system to prevent waste feed:

I. at start up, until the temperature of $950^{\circ} \mathrm{C}$ or $1100^{\circ} \mathrm{C}$ as the case may be.

II. Whenever the temperature of $950^{\circ} \mathrm{C}$ or $1100^{\circ} \mathrm{C}$ as the case may be is not maintained.

III. Whenever emission monitoring show that any emission limits value is exceeded due to disturbances or failures of air pollution control devices.

c) Co-processing plants shall be designed, equipped, built and operated in such a way as to prevent emission into the air giving rise to significant ground level air pollution; in particular; exhaust gases shall be discharged in a controlled fashion and in conformity with ambient air quality standards by means of a stack, the height of which is calculated in such a way as to safeguard human health and the environment.

d) The management of the co- processing plant shall be in the hands of a skilled person, competent to manage the hazardous waste in an environmentally sound manner.

\section{DATA COLLECTION \& ANALYSIS:}

\subsection{Implication in Cement Plant}

The study was carried out for the plant that has two kilns installed, one with the capacity of $1.75 \mathrm{MT}$ and another with 1MT capacity. The conclusions for kiln with 1 MT capacity were drawn. Presently, the plant is using imported coal as the fuel for the production of clinker. The purpose of the study was to find out replacements for the coal which could benefit the industry economically and environmentally.

The wastes having potential for their use as alternative fuel and which were available in good quantity were selected. TYRE DERIVED FUEL was taken into account for use as alternative fuel. The selected wastes have to be characterised, on the basis of which the quantity of the alternative fuel that could be added to the rotary kiln can be evaluated The suitable quantities are decided on the basis of the following factors:

1) The quality of clinker should not be affected. For this, the amount of heavy metals and other minerals entering the clinker should be known and it should not exceed the allowable limit.

2) The emissions should be within the limit.

3) The availability of the desired waste material, that is to be used as a fuel, also governs the quantity of fuel entering the kiln.

4) The cost of waste being used as fuel should not exceed the cost of fossil fuels.

\subsection{TYRE DERIVED FUEL}

Cement kilns are well suited for waste-combustion because of their high process temperature and clinker product and also because limestone feedstock acts as gas cleaning agent. The addition of scrap tyre as fuel can put cement industry and environment in a better position for sustainable development of infrastructure. 1Bilion tyres are produced worldwide each year.

Most of the worldwide generated tyres (65.5\%) are simply dumped in the open or in the landfill. Land filling is very common these days but number of waste tyres is increasing faster every year. The massive stockpiles posses' fire and health hazards. Uncontrolled fires are dangerous as they produce large amount of toxic pollutants containing zinc 
oxides, dioxins, volatile organic compounds, $\mathrm{PAH}$, depending on the combustion condition [15].

Tyres are made up of more than 100 different compounds. The main components are rubber ( $50 \mathrm{wt} \%)$, filters like silica gel or carbon black (25 wt \%), steel (10 wt \%), sulphur (1 wt \%), zinc oxide (1 wt \%) and many other additives like processing oil, plasticizer or vulcanisation accelerators.

Scrap tyres possess high volatile and low ash content, with a high heat value than coal or biomass. The calorific value of tyres is between some $6450 \mathrm{kCal} / \mathrm{kg}$ and $8000 \mathrm{kCal} /$ $\mathrm{kg}$. To substitute 1 ton of coal (some $6100 \mathrm{kCal} / \mathrm{kg}$ ) around $0.76-0.95$ ton of scrap tyres is needed. The net $\mathrm{CO}_{2}$ emission factor is approximately $59 \mathrm{t}$ of $\mathrm{CO}_{2} / \mathrm{TJ}$ for tyres and incineration of coal has emission factor of $96 \mathrm{t} \mathrm{CO}_{2} / \mathrm{TJ}$. Based on the ultimate and proximate analysis it can be said that tyre is a feasible option to be used in cement kilns. Both shredded and whole tyres could be used in kilns.

\subsubsection{Chemical Characteristics}

- Tyres are hydrocarbon based materials, derived from oil and gas.

- Tyres have heat content of $6000-8000 \mathrm{Kcal} / \mathrm{Kg}$, depending upon the type of tyre and degree of wire removal.

A comparison of the proximate analysis indicates that tyres offer efficiency advantages in comparison to coal. On the basis of proximate analysis tyres [Table 4.1] have following characteristics:

a) Tyres have lower moisture content. Since the energy required to heat and vaporize inherent water is generally non-recoverable in the energy conversion process, lower moisture content can translate into higher energy utilization efficiency [16].

b) Tyres have low ash content.

c) Tyre have higher volatile to fixed carbon ratio enhances its ability to combust rapidly and completely.

Table 4.1: Proximate Analysis of Tyres

\begin{tabular}{|c|c|c|}
\hline S.NO. & CHARACTERSTICS & TDF \\
\hline 1. & Moisture & $0.75 \%$ \\
\hline 2. & Fixed Carbon & $21.85 \%$ \\
\hline 3. & Ash & $23.19 \%$ \\
\hline 4. & Volatile Matter & $54.23 \%$ \\
\hline 5. & Calorific Value & $7500 \mathrm{kCal} / \mathrm{kg}$ \\
\hline
\end{tabular}

On the basis of ultimate analysis, [Table 4.2] tyres offer some additional advantages:

a) Tyres have lower sulphur content. It offers additional advantages of decreasing Sulphur oxides emissions compared to coal.

b) Tyres have lower carbon to hydrogen ratio. It theoretically reduces carbon dioxide generation and hydrogen converts to water.

c) Tyres have lower nitrogen content. It can marginally decreases nitrogen oxide emissions.

d) Tyres have higher chlorine content.

Table 4.2: Ultimate Analysis of Tyres

\begin{tabular}{|c|c|c|}
\hline S.NO. & CHARACTERSTICS & TDF \\
\hline 1. & Carbon & $67.33 \%$ \\
\hline 2. & Hydrogen & $5.81 \%$ \\
\hline 3. & Nitrogen & $0.25 \%$ \\
\hline 4. & Sulphur & $1.6 \%$ \\
\hline 5. & Oxygen & $1.64 \%$ \\
\hline
\end{tabular}

For emissions measurement purpose using 2500Nm3/ ton of air, calculations are shown below [Table 4.3]:

Table 4.3: Emissions from $2500 \mathrm{Nm} 3 /$ ton of Air

\begin{tabular}{|c|c|c|}
\hline $\mathrm{CO}_{2}(\mathrm{mg} / \mathrm{Nm} 3)^{*}$ & $\mathrm{SO}_{2}(\mathrm{mg} / \mathrm{Nm} 3)^{* *}$ & $\mathrm{~N}_{2}(\mathrm{mg} / \mathrm{Nm} 3)^{* * *}$ \\
\hline 62.48481034 & 0.579703133 & 188.130864 \\
& & \\
\hline
\end{tabular}

$* \mathrm{CO}_{2}$ (lb/ton of clinker) from fuel-0.0367*\%carbon*(lb fuel/ ton of clinker)

$* * \mathrm{SO}_{2}$ (lb/ton of clinker) from fuel-0.02\%sulpher*(lb fuel/ ton of clinker)

$* * * \mathrm{NO}_{2}(\mathrm{lb} /$ ton of clinker) from fuel-[(\%nitrogen/100)]-

[3.3478(0.0267*\%carbon

$+0.01 *$ sulphur $\%+0.08 * \%$ hydrogen $-0.01 \%$ oxygen $]^{*}$ (lb fuel/ ton of clinker)

The table below shows values for heavy metal analysis of TDF.

Table 4.4: The Heavy Metal Analysis of the Tyre Derived Fuel (TDF)

\begin{tabular}{|c|c|c|}
\hline S.NO. & HEAVY METAL & $\%$ \\
\hline 1. & Mercury & 0.001 \\
\hline 2. & Cadmium & 0.010 \\
\hline 3. & Lead & 0.10 \\
\hline 4. & Chromium & 0.0070 \\
\hline 5. & Zinc & 34.81 \\
\hline
\end{tabular}

\subsubsection{Advantage of Scrap Tyre Over Coal}

- Used tyres have high energy content than coal, which makes them ideal for cement manufacturing i.e. tyre produces $25 \%$ more energy than coal.

- The shredded element of the tyres is consumed totally without having of black output in smoke and odour is normal as of burn tyres.

- Steel reinforcing oxidises and replaces a portion the 
iron used in the cement manufacturing.

- $\quad$ There are no residues with tyre fuel in cement kiln.

- Scrap tyres can be completely destroyed in cement kiln, the combination of extremely high temperatures, a positive oxygen atmosphere and long residence time; assured complete combustion of scrap tyre, the complete precludes products of incomplete combustion [17].

- $\quad$ The quality of cement, while using whole or shredded tyres (TDF) is as good as the quality produced while using coal and petroleum coke mixture [18].
- The ash residue from TDF may contain lower heavy metals content than coal.

If coal is stored improperly on stockpiles, it can self ignite creating a serious fire hazard while in case of scrap tyre storage is not a problem.

The various proportion mixtures (combinations) of tyre derived fuel (Alternative Fuel or hazardous waste) and coal are evaluated in tabular form for their calorific value, heavy metal analysis and emissions. The results are compared with standards established for coal(the main fuel used) in cement kiln. (Table 4.5)

Table 4.5: Check for Suitability of Combination of Coal and TDF

\begin{tabular}{|c|c|c|c|c|c|c|c|c|c|c|}
\hline \multicolumn{2}{|c|}{ Fuel Mix } & \multirow{2}{*}{$\begin{array}{l}\text { Cal.Value } \\
\text { (Kcal/Kg) }\end{array}$} & \multicolumn{5}{|c|}{ Elemental Analysis (\%) } & \multicolumn{3}{|c|}{ Emissions( mg/Nm3) } \\
\hline \%coal & \%TDF & & $\mathbf{H g}$ & Cd & $\mathbf{P b}$ & $\mathbf{C r}$ & Zn & $\mathrm{CO2}$ & SO2 & N2 \\
\hline $100 \%$ & $0 \%$ & 6200 & 0,001 & 0,0001 & 0,001 & 0,01 & 0,01 & 64,22 & 0,4539 & 125,18 \\
\hline $95 \%$ & $5 \%$ & 6265 & 0,001 & 0,0006 & 0,006 & 0,0099 & 1,75 & 64,1332 & 0,460155 & 128,3275 \\
\hline $90 \%$ & $10 \%$ & 6330 & 0,001 & 0,0011 & 0,011 & 0,0097 & 3,49 & 64,0464 & 0,46641 & 131,475 \\
\hline $85 \%$ & $15 \%$ & 6395 & 0,001 & 0,0016 & 0,016 & 0,0096 & 5,23 & 63,9596 & 0,472665 & 134,6225 \\
\hline $80 \%$ & $20 \%$ & 6460 & 0,001 & 0,0021 & 0,021 & 0,0094 & 6,97 & 63,8728 & 0,47892 & 137,77 \\
\hline $75 \%$ & $25 \%$ & 6525 & 0,001 & 0,0026 & 0,026 & 0,0093 & 8,71 & 63,786 & 0,485175 & 140,9175 \\
\hline $70 \%$ & $30 \%$ & 6590 & 0,001 & 0,0031 & 0,031 & 0,0091 & 10,45 & 63,6992 & 0,49143 & 144,065 \\
\hline $65 \%$ & $35 \%$ & 6655 & 0,001 & 0,0036 & 0,036 & 0,009 & 12,19 & 63,6124 & 0,497685 & 147,2125 \\
\hline $60 \%$ & $40 \%$ & 6720 & 0,001 & 0,0041 & 0,041 & 0,0088 & 13,93 & 63,5256 & 0,50394 & 150,36 \\
\hline $55 \%$ & $45 \%$ & 6785 & 0,001 & 0,0046 & 0,046 & 0,0087 & 15,67 & 63,4388 & 0,510195 & 153,5075 \\
\hline $50 \%$ & $50 \%$ & 6850 & 0,001 & 0,0051 & 0,051 & 0,0085 & 17,41 & 63,352 & 0,51645 & 156,655 \\
\hline $45 \%$ & $55 \%$ & 6915 & 0,001 & 0,0055 & 0,055 & 0,0084 & 19,15 & 63,2652 & 0,522705 & 159,8025 \\
\hline $40 \%$ & $60 \%$ & 6980 & 0,001 & 0,006 & 0,06 & 0,0082 & 20,89 & 63,1784 & 0,52896 & 162,95 \\
\hline $35 \%$ & $65 \%$ & 7045 & 0,001 & 0,0065 & 0,065 & 0,0081 & 22,63 & 63,0916 & 0,535215 & 166,0975 \\
\hline $30 \%$ & $70 \%$ & 7110 & 0,001 & 0,007 & 0,07 & 0,0079 & 24,37 & 63,0048 & 0,54147 & 169,245 \\
\hline $25 \%$ & $75 \%$ & 7175 & 0,001 & 0,0075 & 0,075 & 0,0078 & 26,11 & 62,918 & 0,547725 & 172,3925 \\
\hline $20 \%$ & $80 \%$ & 7240 & 0,001 & 0,008 & 0,08 & 0,0076 & 27,85 & 62,8312 & 0,55398 & 175,54 \\
\hline $15 \%$ & $85 \%$ & 7305 & 0,001 & 0,0085 & 0,085 & 0,0075 & 29,59 & 62,7444 & 0,560235 & 178,6875 \\
\hline $10 \%$ & $90 \%$ & 7370 & 0,001 & 0,009 & 0,09 & 0,0073 & 31,33 & 62,6576 & 0,56649 & 181,835 \\
\hline $5 \%$ & $95 \%$ & 7435 & 0,001 & 0,0095 & 0,095 & 0,0072 & 33,07 & 62,5708 & 0,572745 & 184,9825 \\
\hline $0 \%$ & $100 \%$ & 7500 & 0,001 & 0,01 & 0,1 & 0,007 & 34,81 & 62,484 & 0,579 & 188,13 \\
\hline
\end{tabular}

Replacement of coal with TDF provides better calorific value to the fuel. The emissions of the greenhouse gases are also reduced. This contributes to the environmental benefits. It can be concluded from the table that maximum $25 \%$ of the coal can be replaced by the tyre derived fuel (TDF) $[19,20]$. Above this percentage, the value of zinc increases above the standard value i.e. $9 \%$ which affects the quality of the clinker.

\subsubsection{COST \& AVAILABILITY}

TDF can replace coal by $25 \%$ without affecting the quality of clinker. Beyond this percentage zinc increases above the standard limit i.e. 9\%, affecting the settling properties of the cement [21]. The TDF as a fuel costs around Rs.3000 per tonne including the transportation cost whereas coal costs around Rs. 5800.This brings economical benefits to the organisation. If we use $100 \%$ coal, we require $1,25,806$ ton of coal per annum for producing 1 million ton of cement [22]. The total cost of this amount of coal is around 73 crore. Availability of TDF was estimated around 20,000 metric tonne per annum.

\section{CONCLUSION}

Co-processing in the cement industry is the optimum way of recovering energy and material from waste. It offers a safe and sound solution for society, the environment and the cement industry, by substituting non renewable resources with societal waste under strictly controlled conditions. 
The purpose of the study was to find out replacements for the coal for A Cement Plant which could benefit the plant economically and environmentally. For this, the wastes having potential for their use as alternative fuel and which were available in good quantity within the state were selected. TYRE DERIVED FUEL was taken into account for its use as alternative fuel.

The selected wastes have been characterised, on the basis of which the quantity of the alternative fuel that could be added to the rotary kiln has been evaluated. It was found that:

1) TDF can replace $25 \%$ of the coal. Beyond this percentage lead value increases above the limit.

2) Up to this level of replacement the emissions were found to be within the limit.

3) The desired waste material, to be used as a fuel, is available within the state.

4) The cost of waste being used as fuel does not exceed the cost of fossil fuels.

Thus the Co-processing of hazardous substances in cement industry is much beneficial option, whereby hazardous wastes are not only destroyed at a higher temperature of around $14000 \mathrm{C}$ and longer residence time but its inorganic content gets fixed with the clinker apart from using the energy content of the wastes. Apart from this, no residues are left, which in case of incineration still requires being land filled as incinerator ash. Further the acidic gases, if any generated during Co-combustion gets neutralized, since the raw material is alkaline in nature. Such phenomenon also reduces resource requirement such as coal and lime stone. Thus utilization of Hazardous wastes for Co-combustion makes a win -win situation.

\section{REFERENCES}

[1] Lehtonen, M. (2004). The environmental-social interface of sustainable development: capabilities, social capital, institutions. Ecological economics, Vol. 49, No. 2, pp. 199-214, 2004.

[2] Chhabra K.K. et Mathur A.N. 1992; Energy Recovery through Waste Management Techniques; Indian Journal of Environmental Protection, Vol. 12, No. 2, P. 115-122.

[3] http://www.globalwords.edu.au/units/Sustainability_ UPY6_html/pop03.html/(Sustainability and activities for Ida's story and Blueback).

[4]http://thelivinglabiesd.wordpress.com/2012/11/19/ sustainable-waste-sustainable-waste-management/ (Sustainable Waste Management).

[5] Greco C.; Fresh Alternative: Injecting and firing
Alternative fuels in Cement Kiln; International Cement review, P 24-26 1996

[6] Suderman, R.W. et Nisbet, M.A.; Waste derived fuel as a supplementary energy source at the Woodstock Cement Plant; Environment Canada, Report EPS 3/UP/6. 1992.

[7] Xu Xianyu, Yang Liqun, Xiong Qiuxia ; A Study Of Effect Of Zno, Bao, Caf2, Case on formation Rate of clinker; The 3rd Beijing International Symposium on Cement and Concrete, Beijing, China, Vol. 14, P. 209-214. 1993.

[8] The Cement Sustainability Initiative Progress Report; World Buiseness Council For Sustainable Development 2005

[9] Karstensen, K. H.; Guidelines for co-processing; .Proceedings of "China International Conference on the Utilization of Secondary Materials and Fuel in Building Materials Industry: Institute of Technical Information for Building Materials Industry of China; 2009.

[10] Mokrzycki, E., Uliasz-Bocheńczyk, A. et Mieczysław;; Use of alternative fuels in the Polish cement industry; Applied Energy, Vol. 74, pp. 95-100. 2003

[11] Greco C.; November 1996; Fresh Alternative: Injecting and firing Alternative fuels in Cement Kiln; International Cement review, P 24-26.

[12] Inventorization of Hazardous Waste Generation in M.P. U.P., Punjab, Haryana, Rajasthan \& H.P.,Hazardous Waste Management Series; HAZWAMS/3/; CPCB, Delhi; 1995.

[13] Rao, P. N. and Zhang, J. Z. (2009) Green Manufacturing - Environmental effects of soy based cutting fluid, Presented at the ATMAE Convention, November, 2009.

[14] Hubbard, K. M., Callahan, R. N., \& Strong, S. D. (2008). A standardized model for the evaluation of machining coolant/lubricant costs. The International Journal of Advanced Manufacturing Technology, 36(1), 1-10.

[15] Mori M, Fujishima M, Inamusa Y, Oda Y (2011) A Study on Energy Efficiency Improvement for Machine Tools, CIRP Annals - Manufacturing Technology, 60(1),145-148.

[16] Dunker T., Radons G. et Westkamper E. (2005). "Combining evolutionary computation and dynamic programming for solving a dynamic facility layout problem." European Journal of Operational Research. 165, 55-69.

[17] Zhao B., Wang S., Wang J., Joshua S. , Liu F., Jiayu T., Xiao F. and Hao J.; 2013; Impact of National NOx $a n d$ SO2 Control Policies on Particulate Matter Pollution in China; Atmospheric Environment, 77, 453-463.

[18] Mathews J.; 2012; Green Growth Strategies-Korean Initiatives; Futures. 
[19] Xu B., Sun Q.e, Wennersten R. et Brandt N.; 2014; An Analysis of China's Carbon Dioxide Mitigation

Target; Wiley Online Library; Sust. Dev. 22, 113-121.

[20] Wang Y., Zhu Q. and Geng Y, ; 2013; Trajectory and Driving Factors for GHG Emissions in The Chinese

Ccement Industry; Journal of Cleaner Production; 53; 252260.

[21] Romaniuk P. and Foundation S.; 2011; Sustainable Development in The Cement Industry; Sustainable Development Applications; 2, 78-85.

[22] Sumit Gupta, G. S. Dangayach, A. K. Singh 2015 "Key Determinants of Sustainable Product Design and Manufacturing" Procedia CIRP, Volume 26, Pages 99-102 